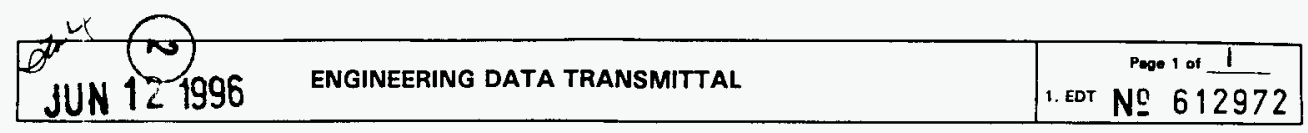

\begin{tabular}{|c|c|}
\hline $\begin{array}{l}\text { 2. To: (Receiving organization) } \\
\text { Distribution }\end{array}$ & $\begin{array}{l}\text { 3. From: Ooriginating Organizati } \\
\text { GPP's/Operations Support }\end{array}$ \\
\hline $\begin{array}{l}\text { 5. Proj./Prog./Dept./Div.: } \\
\dot{P}_{\text {rij }} \text { h }-154\end{array}$ & $\begin{array}{l}\text { 6. Cog. Engr.: } \\
\text { R.W. Matt ichak }\end{array}$ \\
\hline
\end{tabular}

11. Receiver Rentarks:

ion)
4. Related EOT NO.:
N/A
7. Purchase Order No.:
N/A

9. Equip./Component No.:

N/A

10. System/Bldg./Facility:

$$
\text { N/A }
$$

12. Major Assm. Dwg. Mo.:

$N / A$

13. Permit/Permit Application No.: $N / A$

14. Required Response Date:

$$
N / A
$$

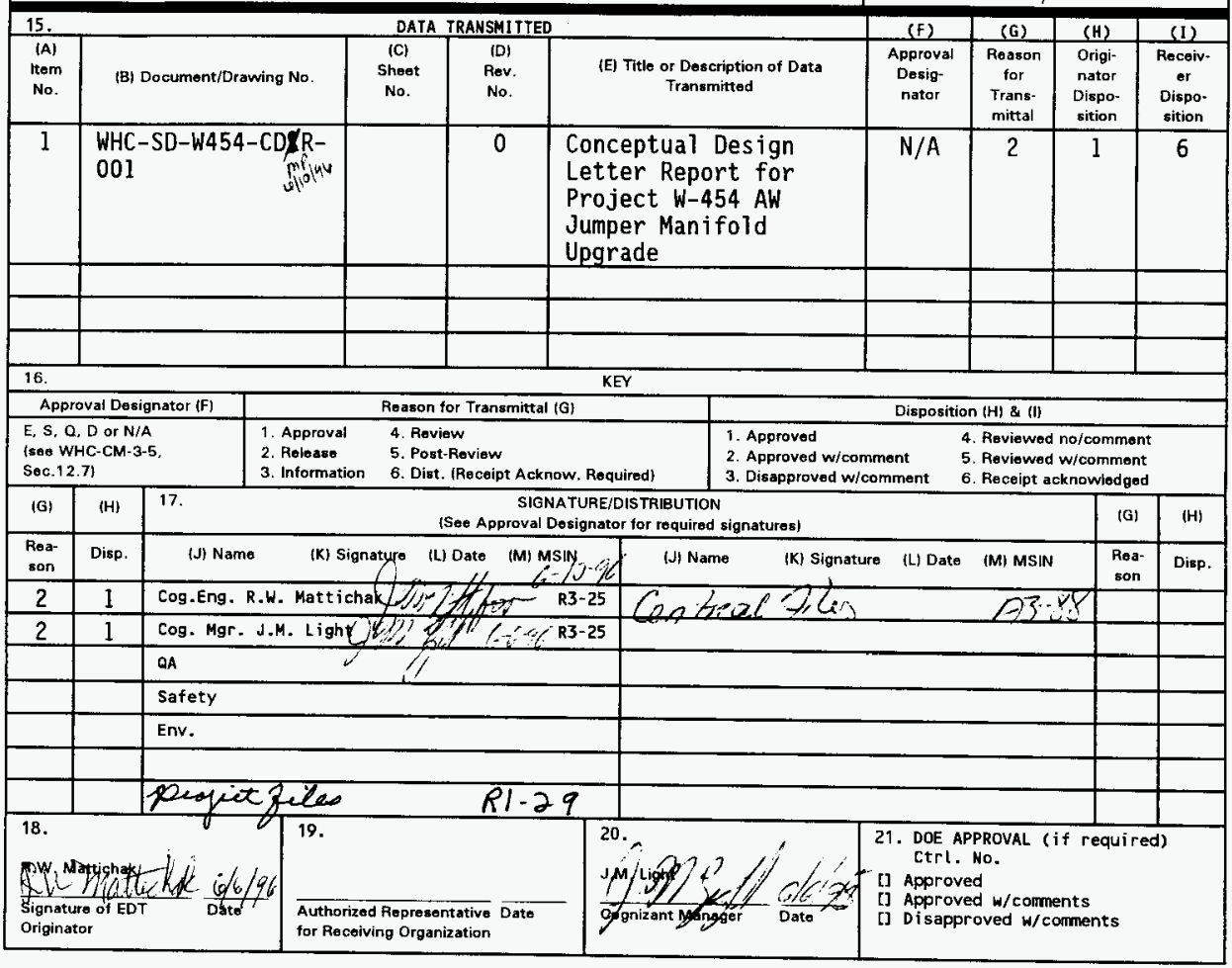

BD-7400-172-2 (04/94) GEF097 


\section{Conceptual Design Letter Report for Project W- 454, AW Jumper Manifold Upgrade}

\section{R. W. Mattichak}

Westinghouse Hanford Company, Richland, WA 99352

U.S. Department of Energy Contract DE-AC06-87RL10930

EDT/ECN: EDT «/Z97Z UC: 2030

Org Code: 8K220

B\&R Code: 31300010

Charge Code: $N 1763$ Kotal Pages: 4142 Kmb\%/.0/46

Key Words: AW, Jumper, Manifold, Upgrade, Conceptual Design

Abstract: This Conceptual Design Letter Report provides details on the activities required to be performed for this project and also provides cost estimates and schedules for those activities.

TRADEMARK DISCLAIMER. Reference herein to any specific comercial product, process, or service by trade name, trademark, manufacturer, or otherwise, does not necessarily constitute or imply its endorsement, recommendation, or favoring by the United States Government or any agency thereof or its contractors or subcontractors.

Printed in the United States of America. To obtain copies of this document, contact: WHC/BCS Document Control Services, P.O. Box 1970, Mailstop H6-08, Richland WA 99352, Phone (509) 372-2420; Fax (509) 376-4989.
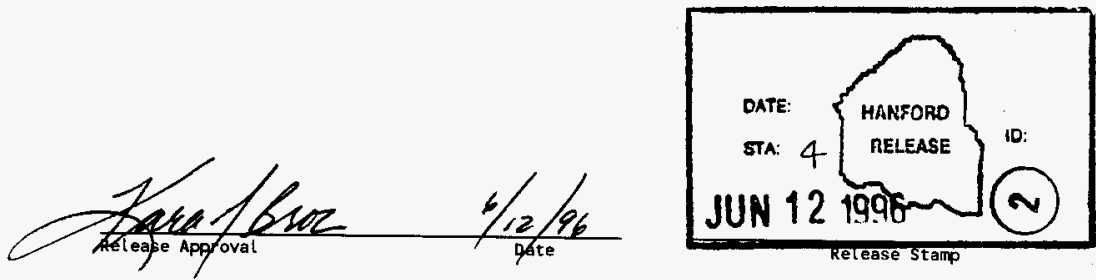

\section{Approved for Public Release}




\title{
CONCEPTUAL DESIGN LETTER REPORT FOR \\ PROJECT W-454 \\ AW JUMPER MANIFOLD UPGRADE
}

\author{
Prepared for
}

\author{
Westinghouse Hanford Company \\ Purchase Order MSJ-SBW-336070 \\ Task Order A95-121 \\ Report No. 951121-001, Rev. 0
}

January 1996

Prepared by: Garry A. Tidrick Steven J. Weaver

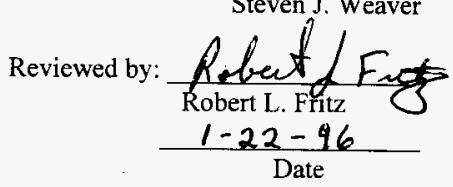




\section{TABLE OF CONTENTS}

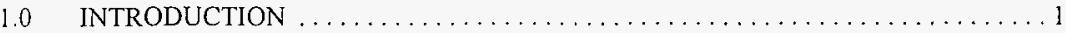

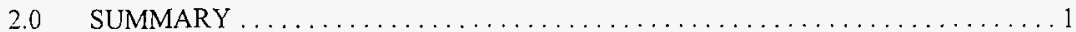

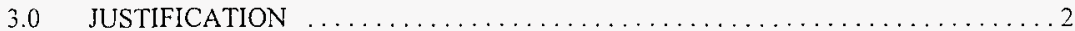

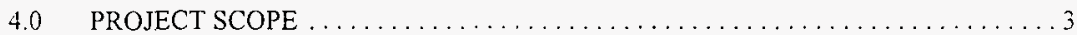

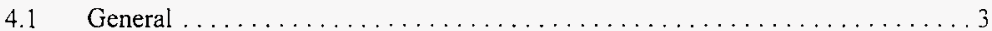

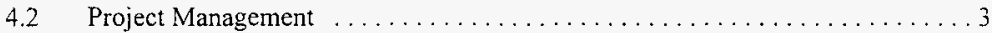

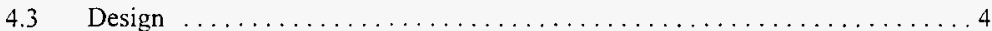

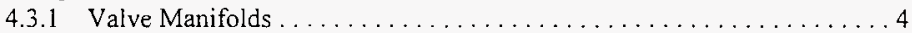

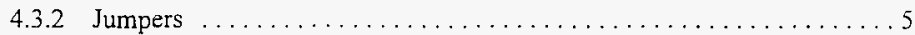

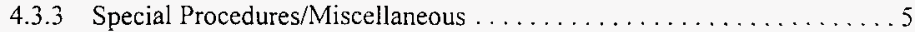

4.3 .4 Cover Blocks . . . . . . . . . . . . . . . . . . . . . . . . . . 6

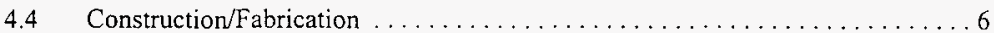

$4.4 .1 \quad$ Valve Manifolds . . . . . . . . . . . . . . . . . . . . . . . . 6

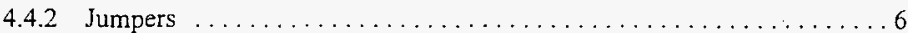

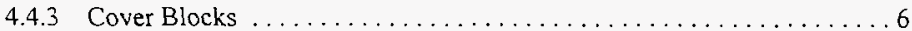

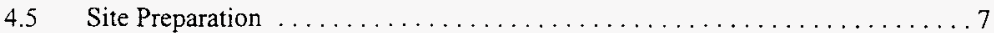

4.5.1 Cover Block Removal . . . . . . . . . . . . . . . . . . . . . 7

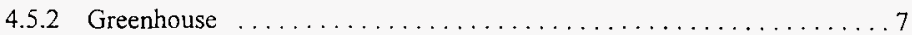

4.5.3 Pit Decontamination ............................ 8

4.5.4 Waste Removal and Disposal $\ldots \ldots \ldots \ldots \ldots \ldots \ldots \ldots \ldots$

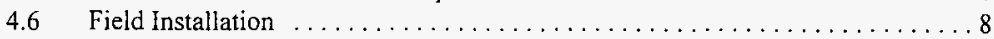

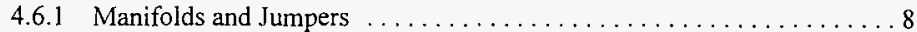

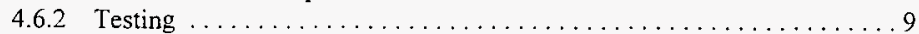

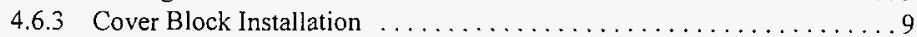

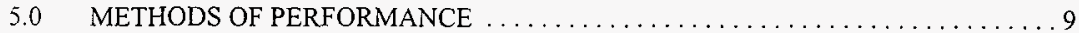

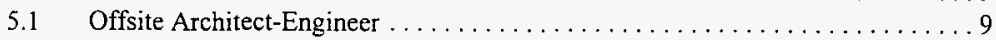

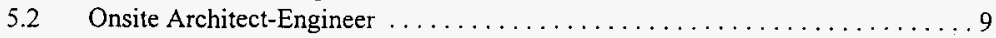

5.3 Procurement Strategy ................................... 9

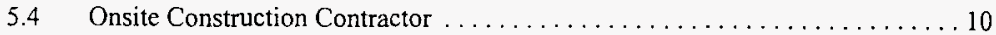

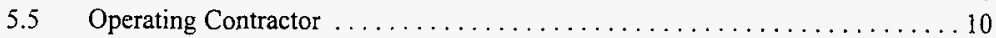

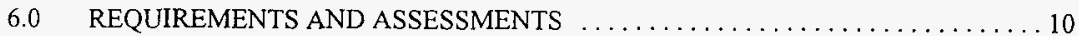

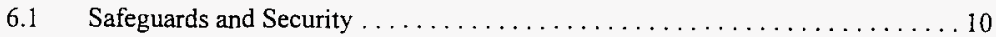


6.2 Health and Safety . . . . . . . . . . . . . . . . . . . . . .

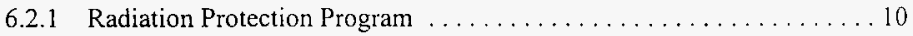

6.2 .2 ALARA . . . . . . . . . . . . . . . . . . . 11

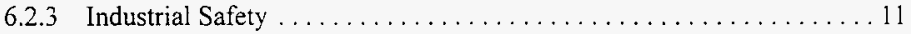

6.3 Quality Assurance/Safety Classification $\ldots \ldots \ldots \ldots \ldots \ldots \ldots \ldots \ldots \ldots$

6.3 .1 Quality Assurance . . . . . . . . . . . . . . . . . . 11

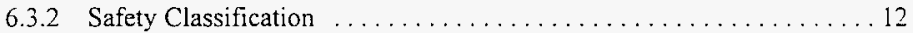

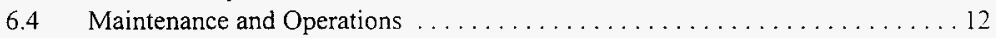

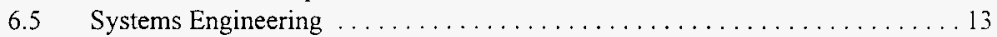

7.0 IDENTIFICATION AND ANALYSIS OF UNCERTAINTIES $\ldots \ldots \ldots \ldots \ldots \ldots$

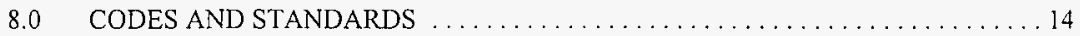

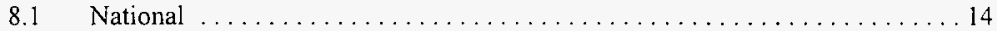

8.2 Hanford Plant Standards . . . . . . . . . . . . . . . . . 14

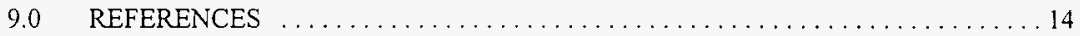

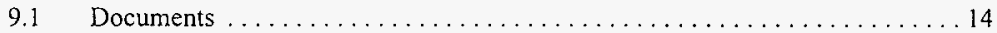

9.2 Drawings ..........................

\section{APPENDICES}

APPENDIX A

Cost Estimate Details

APPENDIX B

Project Schedule

APPENDIX C

Current Operating Practices

APPENDIX D

Life-Cycle Cost Analysis

APPENDIX E

Design Drawings 


\section{$1.0 \quad$ INTRODUCTION}

Project W-454, "AW Jumper Manifold Upgrade," will install valve manifold assemblies and flexible jumpers in Valve Pits 241-AW-A and 241-AW-B. The project will also modify or replace existing valve pit cover blocks to allow for remote operation of the valve manifolds, provide valve pit decontamination, and remove and dispose of the spare contaminated jumpers and other miscellaneous equipment presently stored in the valve pits.

This Conceptual Design Letter Report provides details on the activities required to be performed for this project and also provides cost estimates and schedules for those activities.

\subsection{SUMMARY}

All currently scheduled and future waste transfer operations at the 241-AW Tank Farm, 241-AP Tank Farm, and Evaporator Building 242-A are routed through Valve Pits 241-AW-A and 241AW-B. Under the current operational mode, each time a different waste transfer route is required, valve pit cover blocks are removed, an individual jumper is physically disconnected, a different jumper is installed and the desired waste transfer piping configuration is obtained. The cover blocks are then reinstalled and operations proceed. This method of aligning waste transfer piping requires entry into the valve pit which exposes workers to high radiation levels and is very expensive.

Project W-454 will install valve manifold assemblies that provide all necessary waste routing configurations by remote manual operation of valve handles which extend through the pit cover blocks. The upgrades provided by Project W-454 will allow the use of all waste transfer piping presently routed to Valve Pits 241-AW-A and 241-AW-B without pit entry or installation and/or removal of additional jumpers. The ability to connect new equipment to the manifold in the future will also be provided.

Each valve manifold and jumper assembly will utilize existing Safety Class 3 approved component designs. Assemblies will be fabricated using existing standards and specifications. All testing and inspections will utilize procedures based on existing standards and practices..

The total estimated cost of this project is $\$ 1,907,338$, with a ten-month schedule duration. The details of the design and installation efforts are contained in Section 4 of this report. The cost estimate information and conceptual project schedule are contained in Appendices A and B, respectively. 


\subsection{JUSTIFICATION}

Typically, up to ten valve pit entries are made each year for regular waste transfer operations at AW Tank Farm. In addition, the present schedule for planned evaporator campaigns in the next ten years will require multiple waste transfer routes through the valve pits, requiring a significant numbers of entries into the valve pits to connect waste transfer pipe to the correct staging tank each year.

Each time a pit is opened, the potential for radioactive contamination of personnel or the environment increases.

Personnel exposure is significant for each pit entry since the radiation level where the work is performed (at the pit rail) is $150 \mathrm{mrem} / \mathrm{hr}$ when the valve pit cover blocks are removed. A typical dosage for an individual worker is $60-70 \mathrm{mrem}$ for this job task with a total exposure up to $280 \mathrm{mrem}$.

The total cost to perform these regular jumper configuration changes is approximately $\$ 300,000$ each year. Additional waste transfers in the AW Tank Farm increase this cost proportionally. Appendix $C$ provides additional information on current practices.

Project W-454 is proposed to resolve these issues, and provide long-term benefits through added flexibility, cost reduction, increased safety, and minimized worker exposure.

The ability to transfer waste through Valve Pits 241-AW-A and 241-AW-B is necessary for current and future waste management and retrieval operations. Installation of the jumper manifold upgrade will benefit regular waste transfer operations at AW and AP Tank Farms, current and future evaporator campaigns and future waste management and retrieval operations involving the AW Tank Farm. Radiation levels in the valve pits will be lower, worker radiation exposure will be reduced, and the manifold jumper assembly will provide more flexibility for waste transfers since the effort required to change waste transfer flow paths is considerably less.

Completion of Project W-454 will provide the following benefits:

- $\quad$ Reduce manpower and time requirements necessary to change waste transfer piping routes in the $\mathrm{AW}$ Valve Pit by eliminating jumper reconfiguration through the use of remote manually operated valves.

- $\quad$ Provide ALARA benefits by reducing worker radiation exposure. 
- Reduce radiation levels in the pits and provide better access to leak detection equipment for maintenance, calibration, and repair through pit decontamination efforts and removal of contaminated equipment.

- $\quad$ Reduce the risk of minor Federal and State regulatory violations for storing contaminated waste (jumpers) in non approved storage facilities (pits).

- Provide more flexible transfer schedules and reduce manpower requirements for changing waste transfer routes.

- Support retrieval requirements by providing flexibility in selection of tanks and waste routes without the need to fabricate special jumper configurations. Connection capabilities are provided for new routes and/or installation of retrieval equipment in the valve pits.

A Life-Cycle Cost Analysis for the expected duration of AW Tank Farm usage (present to 2028) shows a payback of the costs associated with Project W-454 in approximately five years. Details of this analysis are shown in Appendix D.

Based on these considerations, Project W-454 is considered appropriate from the safety, compliance, and cost perspectives.

\subsection{PROJECT SCOPE}

\subsection{General}

The project will consist of design and construction activities associated with decontamination and removal of existing pits and removal of spare/excess equipment, modification or replacement of cover blocks, and installation of the new jumpers and valves manifolds. Project management and other support is required during project execution.

\subsection{Project Management}

Project management of the design and construction activities will be required throughout project life. The project engineer assigned will be responsible for maintenance of the technical, cost, and schedule baselines, regular reporting to the U.S. Department of Energy, Richland Operations Office and Westinghouse Hanford Company (WHC) management. Configuration control, and 
coordination of all other project activities necessary to achieve completion will also be accomplished under this activity.

\subsection{Design}

\subsubsection{Valve Manifolds}

Valve manifolds and support structures will be designed that provide all necessary waste routing configurations through Valve Pits 241-AW-A and 241-AW-B. Manifold design will provide for manual alignment of all waste transfer and flush water routings through the use of remote operated valves, without installation or removal of additional jumpers through pit entry. Design and procurement will satisfy Safety Class 3 requirements.

Manifold design will specifically provide for:

- connecting active valve pit nozzles to the valve manifolds utilizing standard flexible jumpers,

- the ability to connect spare pit nozzles and/or new equipment to the valve manifold in the future,

- valving arrangements to ensure two valve isolation from transfer lines/flush piping that is not in the desired flow path,

- all manifolds to be sloped to facilitate drainage of excess water towards the main transfer lines to avoid the trapping of liquids,

- minimizing connector length to minimize waste traps which produce radiation hot spots,

- $\quad$ stainless steel valves and piping to facilitate decontamination and to ensure long term reliability by minimizing failure due to corrosion,

- adequate clearance for calibration, maintenance, and repair of existing leak detection equipment, pit drains, and other equipment in the pits,

- the ability to cross-connect the slurry and supernatant transfer piping, and

- the ability to flush all flow paths. 
The valve manifold will utilize proven valve designs that include provisions for the following:

- manual operation of all valves through the use of extension handles that extend through the valve pit cover blocks.

- removal of valve bodies to allow replacement of components.

- utilization of ultra-high molecular weight polyethylene seat, seal, and stem packing for long-term reliability and increased performance of the valves in a moderate radiation environment.

- positive positioning of all valves (with stop bar) and an operator slot aligned with the valve port.

- verification of ball position with respect to handle and stem markings.

- cam-type interlocks with locking tabs on handles and pit cover blocks for valves in Transfer Line SL-168 and V-021 in Valve Pit 241-AW-A and for valves in Transfer Lines SL-167 V-022, and V-023 in Valve Pit 241-AW-B.

- limit switch indication of valve position on flush water isolation valves with interties to existing interlock circuitry at the electrical junction box adjacent to each pit.

\subsubsection{Jumpers}

Jumpers will be designed in accordance with WHC-SD-RE-DGS-002, Revision 3 , Jumper Design Standard, (Reference 1) to connect each active pit nozzle to the valve manifold. Jumpers will be flexible type with standard PUREX type connectors. Design will satisfy Safety Class 3 requirements.

\subsubsection{Special Procedures/Miscellaneous}

Special isolation and decontamination procedures will be developed by the operating contractor during design. These procedures will be based on existing procedures to the extent possible. 


\subsubsection{Cover Blocks}

Rebar scanning of the existing four cover blocks to determine what. if any, rebar cutting will be necessary to allow reach rods to extend to remote operation will be performed after valve manifold design is complete. Based on the results of this scanning, additional structural analysis will be performed to ensure cover block acceptability. Repairs to account for cut rebar will be designed as required. If necessary or more cost effective, a new cover block will be fabricated.

\subsection{Construction/Fabrication}

\subsubsection{Valve Manifolds}

The valve manifold assemblies will be fabricated and tested in accordance with Hanford Plant Standard (HPS) HS-BS-0084, Jumper Fabrication and Testing Specification, utilizing existing, approved component designs to the extent possible. The valve manifold for each pit will consist of two- and three-way stainless steel ball valves, valve extension handles, lifting bails, valve funnel assemblies, piping, and structural support. The flow configurations, manifold and jumper physical arrangements, and procurement data sheet information are contained in Appendix $E$.

The complete, fully assembled valve manifolds will be hydrostatically tested to 600 psig in accordance with HPS HS-BS-0090, Hydrostatic Testing.

\subsubsection{Jumpers}

Jumpers will be fabricated that connect each active pit nozzle to the valve manifold. Jumpers will be flexible type with standard PUREX type connectors. Thirteen jumpers will be required for Valve Pit 241-AW-A and fifteen jumpers for pit 241-AW-B. Fabrication and testing will be in accordance with HPS HS-BS-0084, Jumper Fabrication and Testing Specification, and will satisfy Safety Class 3 requirements.

The fully assembled flexible jumpers will be hydrostatically tested to $600 \mathrm{psig}$ in accordance with HPS HS-BS-0090, Hydrostatic Testing.

\subsubsection{Cover Blocks}

This project will inspect the existing cover blocks after design of the manifolds is completed to determine if core drills to accept the valve operating extensions handles are 
acceptable. The project will then core drill the valve pit cover blocks as required and make any repairs necessary to correct for rebar which was cut. The modifications will include the following provisions:

- Cover blocks will be core drilled to allow new valve extension handles to extend through the cover blocks.

- Repairs to accommodate structural requirements impacted by rebar cutting will be performed as required.

- Flow diagrams for existing waste transfer piping connections on the cover blocks will be painted out. The new arrangements and flow paths will be painted on the cover blocks.

- Lock tabs will be provided on the cover blocks for valves in transfer lines SL-168 and V-021 (Valve Pit 241-AW-A) and lines SL-167, V-022, and V-023 (Valve Pit 241-AW-B)

\subsection{Site Preparation}

\subsubsection{Cover Block Removal}

The valve pit jumpers and existing process lines will be removed from service and isolated prior to removal of the pit cover blocks. The cover blocks for Valve Pits 241AW-A and 241-AW-B will be removed and stored in an appropriate location. Appropriate decontamination activities will be performed on the removed cover blocks to assure exposure during the performance of modifications is minimized.

The Project will provide a storage area (lay down area) for cover blocks and equipment. A storage area for contaminated equipment will be provided if existing jumpers are not placed directly in the disposal box upon removal.

\subsubsection{Greenhouse}

A greenhouse will be moved into location prior to the beginning of work inside the pits to assure contamination control is maintained. It is assumed that a greenhouse will be available which requires only moderate modification. 


\subsubsection{Pit Decontamination}

The valve pits will require decontamination prior to removal of the existing equipment and installation of the new valve manifolds. Pit drains will also be inspected and verified to be clear of obstructions.

The project will perform radiological surveys and initial decontamination (spray wash) of the pits prior to equipment removal. This initial decontamination effort is performed to allow removal of existing equipment from the valve pits in a manner which minimizes exposure. The project will include provisions to remove residual standing water from the valve pits, by assuring drainage to an appropriate double-shell tank is accomplished after removal of existing equipment.

Final decontamination of the valve pits will be performed after removal is complete to reduce contamination levels as much as possible before new equipment is installed. Final decontamination will utilize hot soapy water and/or chemical cleaning as appropriate.

\subsubsection{Waste Removal and Disposal}

The project will also provide for temporary storage, packaging, transportation, and disposal of solid low-level waste. Piping, jumpers, and miscellaneous equipment stored inside the pits will be removed and decontaminated and/or disposed of as appropriate. Solid radioactive waste such as construction waste and waste generated from the pit decontamination will also require disposal. It is planned that the contaminated equipment/jumpers will require minimal decontamination prior to disposal as low level radioactive waste. Liquid radioactive waste will be returned to the $241-\mathrm{AW}-102$ tank through the pit drain system.

\subsection{Field Installation}

\subsubsection{Manifolds and Jumpers}

The valve manifolds will be placed in the valve pits following removal of existing equipment and jumpers and final decontamination of the pits. The valve manifolds will then be connected to the pit nozzles with the flexible jumpers. The manifold will be attached to structural members which rest (unanchored) on the pit floor. 


$\begin{array}{lr}\begin{array}{l}\text { PROJECT W-454 - CONCEPTUAL DESIGN LetTER REPORT } \\ \text { - Report No. } 951121-001\end{array} & \text { WHC-SD-W454-CD } / \text { R-00t, Rev, } 0 \\ \text { January } 1996\end{array}$

\subsubsection{Testing}

The project will perform in-service inspection of the jumper connections at the pit nozzles. The inspection will be performed at the normal operating pressure utilizing fiush water line pressure. The jumper connections at the valve manifold will be lested prior to installation of the valve manifold and jumper assemblies in the valve pits.

\subsubsection{Cover Block Installation}

The modified cover blocks will be reinstalled prior to testing of the hot tie-in connections. The ability of the reach rods to accurately align all valves will be confirmed. The covet blocks will then be sealed to prevent the release of contamination to the environment and to provide weather protection (rain. snow, and dust), and final removal of all equipment and waste completed.

\subsection{METHODS OF PERFORMANCE}

\subsection{Offsite Architect-Engineer}

An offsite architect-engineer will provide the Definitive Design for this project. It is anticipated that an existing task order agreement will be utilized to minimize schedule impact due to processing time required for new contracts. Procedures related to operations which require revision will be revised as appropriate by Tank Waste Remediation System (TWRS) Engineering support personnel.

\subsection{Onsite Architect-Engineer}

The onsite engineer/construction contractor will perform engineering support during construction and Acceptance Inspection on this project.

\subsection{Procurement Strategy}

The operating contractor will procure the valve manifolds from an offsite equipment manufacturer through the standard procurement process. 


\subsection{Onsite Construction Contractor}

The onsite engineer/construction contractor will perform jumper fabrication, decontamination of valve pits, installation of valve manifolds and jumpers, and modification of cover blocks. Pit decontamination may be performed by the operating contractor dependent upon initial survey results, and the Plant Forces Work Review process.

\section{$5.5 \quad$ Operating Contractor}

The operating contractor will provide overall project management during design, procurement, and construction of the project, safety support, procurement services, and operations support during Isolation, installation, and testing. Disposal of solid waste will also be by the operating contractor.

\subsection{REQUIREMENTS AND ASSESSMENTS}

\subsection{Safeguards and Security}

Upgrades provided by Project W-454 will be performed within the 200 East Area security fenced area. Existing safeguards and security measures will not be impacted by this project and new measures beyond current practices are not required.

\subsection{Health and Safety}

\subsubsection{Radiation Protection Program}

Project W-454 will require personnel to work in Valve Pits 241-AW-A and 241-AW-B. Removal of valve pit cover blocks and personnel entry into valve pits may expose workers to high radiation levels as well as loose surface and airborne contamination. Personnel access to the valve pits will be controlled by the Health Physics Technician (HPT). Radiation, loose surface contamination, and airborne contamination levels will be determined by the HPT and the appropriate work practices, administrative measures, and controls will be implemented based on the requirements of WHC-CM-1-6, Radiation Control Manual (Reference 3). 


\subsubsection{ALARA}

The project will prepare and implement an ALARA plan. The project will implement design and administrative practices that will limit radiation and toxicological exposure to ALARA standards. Worker exposures will be monitored and maintained to meet ALARA standards in accordance with Hanford Site practices and procedures.

\subsubsection{Industrial Safety}

Routine construction hazards will exist during performance of this project. Removal and replacement of valve pit cover blocks will require the use of a crane. Hazards may include dropping of a pit cover block caused by crane failure, operator error, or rigging failure. It is assumed that personnel entry into Valve Pits 241-AW-A and 241-AW-B does not constitute confined space entry. If the valve pits are considered a confined space, then additional hazards could be present, such as exposure to toxic gas, and a confined space entry permit would be required.

Hazards associated with construction activities will be considered and mitigated to the extent practical. All reasonable precautions will be taken to protect the safety and health of personnel, including placement of removable guardrails around the perimeter of each valve pit when cover blocks are removed, and regular safety inspections by safety personnel and management.

\subsection{Quality Assurance/Safety Classification}

\subsubsection{Quality Assurance}

Project activities for contractors involved in design, procurement, construction, and acceptance will be governed by U.S. Department of Energy (DOE) Order 5700.6C, Quality Assurance (Reference 4). Minimum project quality attributes are included in the project Functional Design Criteria (FDC). The specific technical and quality programmatic requirements, material certifications, qualification and certification of personnel, inspections, examinations and testing, and applicable quality assurance records will be established during definitive design and included in design/procurement documents. 


\subsubsection{Safety Classification}

Safety classifications will be identified for those systems, components, and structures important to safety or environmental protection so that appropriate efforts will be placed on design, procurement, construction, testing. operation, maintenance, and modifications.

Safety classification criteria and methodology are defined in WHC document WHC-CM1-3, Management Requirements and Procedures Manual, (Reference 5), MRP 5.46, and WHC-CM-4-46, Non-Reactor Facility Safety Analysis Manual, (Reference 6), Section 9.0. Safety classifications will be determined through analysis and consequences of failure based on information contained in the project FDC and/or existing safety analysis documents.

The preliminary safety classifications of systems, components, and structures for this project are Safety Class 3 for the valve manifold and jumper assemblies and Safety Class 1 for the valve pit cover blocks (structural attribute only).

\subsection{Maintenance and Operations}

The valve manifold and jumper assemblies will be designed to allow access for maintenance, repair, and replacement of manifold components and jumpers. Manifold design will also provide clearance for maintenance, repair, and replacement of existing valve pit equipment (leak detectors, etc.). Components will be selected and installed to minimize the maintenance effort during normal use. The following criteria will be used in the Detailed Design whenever possible:

- use standard industrial and interchangeable parts,

- provide access for disassembly, repair, and/or replacement,

- provide for maintenance with standard tools, and

- maintain ALARA worker radiation exposure during operations and maintenance.

Equipment installed by this project is expected to require a minimal amount of maintenance, primarily the replacement of non-metallic valve parts approximately every five to ten years. No additional maintenance or operations personnel for AW Tank Farm will be required as a result of this project. 


\subsection{Systems Engineering}

The waste handling functions supported by this project support the TWRS functional requirements associated with:

- Manage tank waste,

- Retrieve tank waste, and

- Process tank waste.

All technical requirements will be in accordance with the specific "transfer waste" functional requirements and will be compatible with the existing architecture.

\subsection{IDENTIFICATION AND ANALYSIS OF UNCERTAINTIES}

An assumption has been made that the existing valve pit cover blocks are suitable for reuse after modification. If one or more of the existing valve pit cover blocks cannot be used as is after core drilling modifications, then repair of existing cover blocks or fabrication of replacement cover blocks could be required. Valve pit cover blocks will still satisfy Safety Class 1 requirements. Modification to existing cover blocks or fabrication of new cover blocks (Safety Class 1) and disposal of existing cover blocks is a considerable amount of work that will involve significant cost. Sufficient continency to accommodate/modification replacement has been allocated in the cost estimate.

An assumption has been made that design pressure for the valve manifolds and jumpers system is $400 \mathrm{psig}$. This assumption must be verified. If design pressure is higher than $400 \mathrm{psig}$, then an appropriate change should be made to the specified hydrostatic test pressure.

Levels of contamination are unconfirmed, however, the decontamination efforts are considered capable of reducing these to acceptable levels based on past experience with similar efforts.

The amount of solid waste to be removed from the valve pits is uncertain. Assumptions on the quantity of material are based on standard jumpers/components. 


\subsection{CODES AND STANDARDS}

\subsection{National}

- American Society of Mechanical Engineers (ASME)

B31.3-1993 Chemical Plant and Petroleum Refinery Piping

- American Society of Testing and Materials (ASTM)

A 36 Standard Specification for Structural Steel

A 312-91b Standard Specification for Seamless and Welded Austenitic Stainless Steel Pipe

A 403-91 Standard Specification for Wrought Austenitic Stainless Steel Pipe Fittings

\subsection{Hanford Plant Standards}

HS-BS-0015 Assembly Identification Specification

HS-BS-0084 Jumper Fabrication and Testing Specification

HS-BS-0090 Hydrostatic Testing

\subsection{REFERENCES}

\subsection{Documents}

1. Carter, S.B., 1988, Jumper Design Standard, SD-RE-DGS-002, Revision 3, Westinghouse Hanford Company, Richland, Washington.

2. Mattichak, R., 1994, Functional Design Criteria, W-454 AW Pit Jumper Manifold Upgrade, WHC-SD-FDC-454-01, Westinghouse Hanford Company, Richland, Washington. 
3. WHC 1995, Radiological Design Guide, WHC-SD-GN-DGS-30011, Westinghouse Hanford Company, Richland, Washington.

4. DOE Order 5700.6C, Quality Assurance, U.S. Department of Energy, Washington, D.C.

5. WHC 1995, Management Requirements and Procedures Manual, WHC-CM-1-3, Westinghouse Hanford Company, Richland, Washington.

6. WHC 1995, Non-Reactor Facility Safety Analysis Manual, WHC-CM-4.46, Westinghouse Hanford Company, Richland, Washington.

\subsection{Drawings}

H-2-57901 Flexible Metal Hose

$\mathrm{H}-2-75017$ Flexible Jumper Assembly 2PH-2-PV-2

$\mathrm{H}-2-75032$ Flexible Jumper Assembly 2PH-2-PH-2

H-2-76946 Jumper Assembly 241-AW-B-R5-R14-R17

H-2-90161 Standard Rigid Lifting Bails

H-2-9017l Standard Valve Funnel Assembly

H-2-90172 Standard Valve Funnel Extension Handle

H-2-90185 Male Nozzle 2" PUREX

H-2-90186 Male Nozzle 3" PUREX

H-2-96873 Jumper Assembly Flexible Jumper 3" Process 
This appendix contains:

- Assumptions used as the estimate basis,

- A summary by WBS of the estimated costs associated with this project,

- A detailed take off of construction material and equipment and installation costs, and

- Contingency Analysis.

\section{APPENDIX A \\ Cost Estimate Details}




\section{Estimate Basis}

The following assumptions form the basis for the estimate details which follow:

- Decontamination of the pits and existing jumpers will be completed to a level acceptable for construction activities to be completed within exposure guidelines.

- Disposal of the existing jumpers and components will be accomplished through triple rinsing and burial in the low-level waste repository.

- Jumper fabrication will be accomplished by the onsite jumper fabrication shop.

- CPAF forces will perform the installation.

- Existing greenhouses (with minor modifications) will be utilized for pit work.

- Both pits will be worked at the same time but coordinated to use the same crews and the same equipment to the maximum extent possible.

- HPT support will be available to support construction efforts.

- Crane rental will be required to perform the cover block removal and equipment installation.

- A maximum of one cover block on each pit would require replacement. Other modifications to account for rebar cut during core drills will be minimal.

- Manifold design will be performed by fixed-price design contractor.

- Manifold construction will be by fixed price local contractor.

- The estimated cost for the support functions (Project Management, Quality Assurance, Safety, etc.) is based upon past costs for similar projects in radiation zones. 
ARES Corporation

DETAILED ESTIMATING WORKSHEET

Task A95-121

Project W-454, AW Jumper Manifold Upgrade

\begin{tabular}{|c|c|c|c|c|c|c|c|c|}
\hline & & $\begin{array}{l}\text { Estimate } \\
\text { Subtotal }\end{array}$ & & tion & Subtotal & Cor & ency & Total Dollars \\
\hline WBS & Activity & & $\%$ & Total & & $\%$ & Total & \\
\hline 1.1 & Project Management & $\$ 113,875$ & $2.0 \%$ & $\$ 2,278$ & $\$ 116,153$ & $20.0 \%$ & $\$ 22,988$ & $\$ 139,141$ \\
\hline 1.2 & Design & $\$ 201,100$ & $2.1 \%$ & $\$ 4,177$ & $\$ 205,277$ & $25.8 \%$ & $\$ 52,944$ & $\$ 258,221$ \\
\hline 1.3 & Construction & $\$ 1,098,697$ & $2.5 \%$ & $\$ 27,563$ & $\$ 1,126,260$ & $28.0 \%$ & $\$ 312,871$ & $\$ 1,439,131$ \\
\hline 1.4 & NEPA/Safety Analysis/Permits & $\$ 24,000$ & $2.0 \%$ & $\$ 480$ & $\$ 24,480$ & $15.0 \%$ & $\$ 3,672$ & $\$ 28,152$ \\
\hline 1.5 & Startup Activities & $\$ 33,000$ & $3.5 \%$ & $\$ 1,155$ & $\$ 34,155$ & $25.0 \%$ & $\$ 8,539$ & $\$ 42,694$ \\
\hline TOTAL & & $\$ 1,470,672$ & $2.4 \%$ & $\$ 35,653$ & $\$ 1,471,827$ & $27.2 \%$ & $\$ 401,014$ & $\$ 1,907,338$ \\
\hline
\end{tabular}


ARES Corporation

DETAILED ESTIMATING WORKSHEET

Project W-454, AW Jumper Manifold Upgrade

\begin{tabular}{|c|c|c|c|c|c|c|c|c|}
\hline & Project Management & $\begin{array}{l}\text { Estimate } \\
\text { Subtotal }\end{array}$ & \multicolumn{2}{|c|}{ Escalation } & Subtotal & \multicolumn{2}{|c|}{ Contingency } & Total Dollars \\
\hline WBS & Activity & & $\%$ & Total & & $\%$ & Total & \\
\hline 1.1 .1 & Project Management (Note 1) & $\$ 46,875$ & $2.0 \%$ & $\$ 938$ & $\$ 47,813$ & $10.0 \%$ & $\$ 4,781$ & $\$ 52,594$ \\
\hline 1.1 .2 & Design Support (Note 2) & $\$ 15,000$ & $2.0 \%$ & $\$ 300$ & $\$ 15,300$ & $15.0 \%$ & $\$ 2,295$ & $\$ 17,595$ \\
\hline 1.1 .3 & Field Support (Note 3) & $\$ 52,000$ & $2.0 \%$ & $\$ 1,040$ & $\$ 53,040$ & $30.0 \%$ & $\$ 15,912$ & $\$ 68,952$ \\
\hline & TOTAL & $\$ 113,875$ & $2.0 \%$ & $\$ 2,278$ & $\$ 116,153$ & $19.8 \%$ & $\$ 22,988$ & $\$ 139,141$ \\
\hline
\end{tabular}

Notes: 1) 1/4 FTE PROJECT ENGINEER, 1/8 FTE PROJECT CONTROLS, 1/8 FTE SAFETYAND MISCELLANEOUS SUPPORT

2) 6 MAN WEEKS OF SUPPORT TIME FOR DESIGN REVIEW (OPS, QA, SAFETY, RAD CONTROL)

3) ONE FTE HEALTH PHYSICS SUPPORT PERSON FOR FIVE-MONTH DURATION DURING CONSTRUCTION 
ARES Corporation

DETAILED ESTIMATING WORKSHEET

PROJECT W-454 AW JUMPER MANIFOLD UPGRADE

\begin{tabular}{|c|c|c|c|c|c|c|c|c|}
\hline & Design & $\begin{array}{l}\text { Estimate } \\
\text { Subtotal }\end{array}$ & \multicolumn{2}{|c|}{ Escalation } & Subtotal & \multicolumn{2}{|c|}{ Contingency } & Total Dollars \\
\hline WBS & Activity & & $\%$ & Total & & $\%$ & Total & \\
\hline 1.2.1 & Definitive Design ( Note 1) & $\$ 126,000$ & $2.0 \%$ & $\$ 2,520$ & $\$ 128,520$ & $28.0 \%$ & $\$ 35,986$ & $\$ 164,506$ \\
\hline 1.2 .2 & $\begin{array}{l}\text { Design During } \\
\text { Construction (Note 2) }\end{array}$ & $\$ 25,200$ & $2.0 \%$ & $\$ 504$ & $\$ 25,704$ & $30.0 \%$ & $\$ 7.711$ & $\$ 33,415$ \\
\hline 1.2 .3 & Title III Inspection (Note 3) & $\$ 31,000$ & $2.5 \%$ & $\$ 775$ & $\$ 31,775$ & $20.0 \%$ & $\$ 6,355$ & $\$ 38,130$ \\
\hline 1.2 .4 & $\begin{array}{l}\text { A/E Project } \\
\text { Management/Support } \\
\text { (Note 4) }\end{array}$ & $\$ 18,900$ & $2.0 \%$ & $\$ 378$ & $\$ 19,278$ & $15.0 \%$ & $\$ 2,892$ & $\$ 22,170$ \\
\hline & TOTAL & $\$ 201,100$ & $2.1 \%$ & $\$ 4,177$ & $\$ 205,277$ & $25.8 \%$ & $\$ 52,944$ & $\$ 258,221$ \\
\hline
\end{tabular}

NOTES: 1) SEE ESTIMATE DETAIL. FOR WBS 1.2.1.1 FOR DEFINITIVE DESIGN DETAILS

2) CALCULATED AT $20 \%$ OF DEFINITIVE DESIGN COSTS BASED ON HISTORICAL DATA

3) BASED ON 180 WELD RECORD INSPECTIONS, 60 CORE DRILLS, 10 FLUSHES, 2 ATPS, AND $\$ 8,000$ FOR ECNS, JUMPER TESTS, AND RECORD CL.OSEOUT 
ARES Corporation

Detailed Estimating Worksheet

Project W-454 AW Manifold Upgrade

\begin{tabular}{|c|c|c|c|c|c|c|c|c|}
\hline & Definitive Design & Estimate Subtotal & \multicolumn{2}{|c|}{ Escalation } & \multirow[t]{2}{*}{ Subtotal } & \multicolumn{2}{|c|}{ Contingency } & Total Dollars \\
\hline WES & Activity & & $\%$ & Total & & $\%$ & Total & \\
\hline 1.2.1.1 & $\begin{array}{l}\text { Cover Block Modifications } \\
\text { (Note 1) }\end{array}$ & $\$ 20,400$ & $2.0 \%$ & $\$ 408$ & $\$ 20,808$ & $28.0 \%$ & $\$ 5,826$ & $\$ 26,634$ \\
\hline 1.2.1.2 & $\begin{array}{l}\text { Manifold Design } \\
\text { (Note 2) }\end{array}$ & $\$ 52,000$ & $2.0 \%$ & $\$ 1,040$ & $\$ 53.040$ & $28.0 \%$ & $\$ 14,851$ & $\$ 67,891$ \\
\hline 1.2.1.3 & $\begin{array}{l}\text { Special Procedure } \\
\text { Preparation (Note 3) }\end{array}$ & $\$ 25,600$ & $2.0 \%$ & $\$ 512$ & $\$ 26,112$ & $28.0 \%$ & $\$ 7,311$ & $\$ 33,423$ \\
\hline 1.2.1.4 & ATP Prep & $\$ 8,000$ & $2.0 \%$ & $\$ 160$ & $\$ 8,160$ & $28.0 \%$ & $\$ 2,285$ & $\$ 10,445$ \\
\hline 1.2.1.5 & Instrumentation ( Note 4) & $\$ 3.900$ & $2.0 \%$ & $\$ 78$ & $\$ 3,978$ & $28.0 \%$ & $\$ 1,114$ & $\$ 5,092$ \\
\hline 1.2 .1 .6 & \begin{tabular}{|l} 
Miscellaneous Details \\
(Note 5)
\end{tabular} & $\$ 16,100$ & $2.0 \%$ & $\$ 322$ & $\$ 16,422$ & $28.0 \%$ & $\$ 4,598$ & $\$ 21,020$ \\
\hline & TOTAL. & $\$ 126,000$ & $2.0 \%$ & $\$ 2,520$ & $\$ 128,520$ & $28.0 \%$ & $\$ 35,986$ & $\$ 164,506$ \\
\hline
\end{tabular}

Notes: 1) Assumes 2 drawings at $120 \mathrm{hrs} / \mathrm{dwg}, \$ 85 / \mathrm{hr}$ (avg)

2) Assumes 8 drawings at $100 \mathrm{hrs} / \mathrm{dwg}, \$ 65 / \mathrm{hr}$ (avg)

3) Assumes 2 special procedures (Decon, Removal/ Installation) at $160 \mathrm{hrs}$. each, $\$ 80 / \mathrm{hr}$. (avg)

4) Assumes $1 \mathrm{dwg}, 60 \mathrm{hrs}, \$ 65 / \mathrm{hr}$

5) Assumes $80 \mathrm{hrs}$ for bid package assembly at $\$ 65 / \mathrm{hr}, 60 \mathrm{hrs}$. rebar scan at $\$ 80$ and $\$ 6100$ of travel, reproduction, and document control. 
ARES Corporation

DETAILED ESTIMATING WORKSHEET

Project W-454 - AW Manifold Upgrade

\begin{tabular}{|c|c|c|c|c|c|c|c|c|}
\hline \multirow[b]{2}{*}{ WBS } & \multirow{2}{*}{$\frac{1.3 \text { Construction }}{\text { Activity }}$} & \multirow[t]{2}{*}{$\begin{array}{l}\text { Estimate } \\
\text { Subtotal }\end{array}$} & \multicolumn{2}{|c|}{ Escalation } & \multirow[t]{2}{*}{ Subtotal } & \multicolumn{2}{|c|}{ Contingency } & \multirow[t]{2}{*}{ Total Dollars } \\
\hline & & & $\%$ & Total & & $\%$ & Total & \\
\hline 1.3.1 & Cover Blocks & $\$ 95,000$ & $3.0 \%$ & $\$ 2,850$ & $\$ 97,850$ & $35 \%$ & $\$ 34,248$ & $\$ 132,098$ \\
\hline 1.3 .2 & Decon/Disposal & $\$ 87,000$ & $2.0 \%$ & $\$ 1,740$ & $\$ 88,740$ & $35 \%$ & $\$ 31,059$ & $\$ 119,799$ \\
\hline 1.3 .3 & Jumper Fab/Install & $\$ 452,760$ & $2.0 \%$ & $\$ 9,055$ & $\$ 461,815$ & $30 \%$ & $\$ 138,545$ & $\$ 600,360$ \\
\hline 1.3 .4 & $\begin{array}{l}\text { Piping System/ } \\
\text { Valves/Misc }\end{array}$ & $\$ 178,672$ & $3.0 \%$ & $\$ 5,360$ & $\$ 184,032$ & $25 \%$ & $\$ 46,008$ & $\$ 230,040$ \\
\hline 1.3 .5 & $\begin{array}{l}\text { Radiation Zone } \\
\text { Inefficiency Factor } \\
\text { (note 1) }\end{array}$ & $\$ 41,235$ & $3.0 \%$ & $\$ 1,237$ & $\$ 42,472$ & $30 \%$ & $\$ 12,742$ & $\$ 55,214$ \\
\hline 1.3 .6 & $\begin{array}{l}\text { Construction Support } \\
\text { (note 2) }\end{array}$ & $\$ 244,030$ & $3.0 \%$ & $\$ 7,321$ & $\$ 251,350$ & $20 \%$ & $\$ 50,270$ & $\$ 301,621$ \\
\hline & PROJECT TOTAL & $\$ 1,098,697$ & $2.5 \%$ & $\$ 27,563$ & $\$ 1,126,260$ & $28 \%$ & $\$ 312,871$ & $\$ 1,439,131$ \\
\hline
\end{tabular}

Note 1-Calculated at $15 \%$ of construction cost of Zone Work

Note 2-Calculated at $30 \%$ of Construction Costs. Includes Sales Tax, Contract Administration, QA, Badging, etc 
Project $w-454$

AW Jumper Manifold Upgrade

Estimate Detail for Construction Activities

\begin{tabular}{|c|c|c|c|c|c|c|c|}
\hline \begin{tabular}{|l|} 
WBS \\
1.3 .1
\end{tabular} & Activity & Quantity & $\begin{array}{c}\text { Mian } \\
\text { Hours }\end{array}$ & Labor & $\begin{array}{c}\text { Equipment/ } \\
\text { Material }\end{array}$ & $\begin{array}{c}\text { Overhead } \\
\text { Profit }\end{array}$ & Total Cost \\
\hline \multirow[t]{5}{*}{1.3 .1} & $\begin{array}{l}\text { Cover Blocks } \\
\text { Remove /decon/modify }\end{array}$ & & & & & & \\
\hline & $\begin{array}{l}\text { Remove /decon/modify } \\
\text { Crane usage }\end{array}$ & 1 LS & 350 & $\$ 21,000.00$ & $\$ 0.00$ & $\$ 0.00$ & $\$ 21,000.00$ \\
\hline & Crane usage & $1 \mathrm{LS}$ & 100 & $\$ 6,000.00$ & $\$ 50,000.00$ & $\$ 0.00$ & $\$ 56,000,00$ \\
\hline & Install/seal/paint & & 300 & $\$ 18,000.00$ & $\$ 0.00$ & $\$ 0.00$ & $\$ 18,000.00$ \\
\hline & Total WBS 1.3 .1 & & 750 & $\$ 45,000.00$ & $\$ 50,000.00$ & $\$ 0.00$ & $\$ 95,000.00$ \\
\hline \multirow[t]{7}{*}{1.3 .2} & Decontamination/Disposal & & & & & & \\
\hline & Special Work Procedure & $1 \mathrm{LS}$ & 200 & $\$ 12,000.00$ & $\$ 0.00$ & $\$ 0.00$ & $\$ 12.000 .00$ \\
\hline & Eslablish greenhouse & $1 \mathrm{LS}$ & 150 & $\$ 9,000.00$ & $\$ 2,000.00$ & $\$ 0.00$ & $\$ 11,000,00$ \\
\hline & Removal of supports & $1 \mathrm{LS}$ & 165 & $\$ 10,000.00$ & $\$ 2,000.00$ & $\$ 0.00$ & $\$ 12,000.00$ \\
\hline & Decon pits & $1 \mathrm{LS}$ & 200 & $\$ 12,000.00$ & $\$ 2,000.00$ & $\$ 0.00$ & $\$ 14,000.00$ \\
\hline & Dispose of equipment/burial & $1 \mathrm{LS}$ & 150 & $\$ 15,000.00$ & $\$ 23,000,00$ & $\$ 0.00$ & $\$ 38,000,00$ \\
\hline & Total WBS 1.3.2 & & 865 & $\$ 58,000.00$ & $\$ 29,000.00$ & $\$ 0.00$ & $\$ 87,000.00$ \\
\hline \multirow[t]{6}{*}{1.3 .3} & Jumper Fabrication//nstallation & & & & & & \\
\hline & 2" horizontal $(5 \mathrm{req})$ & $1 \mathrm{LS}$ & 0 & $\$ 0.00$ & $\$ 64,680.00$ & $\$ 0.00$ & $\$ 64,680.00$ \\
\hline & 2" vertical (9 req) & $1 \mathrm{LS}$ & 0 & $\$ 0.00$ & $\$ 116,424.00$ & $\$ 0.00$ & $\$ 116,424.00$ \\
\hline & 3" horizontal (7 req) & $1 \mathrm{LS}$ & 0 & $\$ 0.00$ & $\$ 135,828.00$ & $\$ \$ 0.00$ & $\$ 135,828.00$ \\
\hline & 3" vertical $(7 \mathrm{req})$ & $1 L S$ & 0 & $\$ 0.00$ & $\$ 135.828 .00$ & $\$ 0.00$ & $\$ 135,828.00$ \\
\hline & Total WBS 1.3.3 & & $\overline{0}$ & $\$ 0.00$ & $\$ 452.760 .00$ & 50.00 & $\$ 452.760 .00$ \\
\hline \multirow[t]{19}{*}{1.3 .4} & Manifold & & & & & & \\
\hline & $\begin{array}{l}\text { Fabrication/lnstallation } \\
\text { 2" 2-way SST valves }\end{array}$ & 16 ea & 0 & $\$ 0.00$ & $\$ 14.661 .00$ & $\$ 3,225.42$ & $\$ 17.886 .42$ \\
\hline & 3" 2-way SST valves & 16 ea & 0 & $\$ 0.00$ & $\$ 25.872 .00$ & $\$ 5,691.84$ & $\$ 31,563.84$ \\
\hline & 2" 3-way SST valves & 11 ea & 0 & $\$ 0.00$ & $\$ 9.486 .00$ & $\$ 2,086.92$ & $\$ 11,572.92$ \\
\hline & 3" 3-way SST valves & 14 ea & 0 & $\$ 0.00$ & $\$ 30,184.00$ & $\$ 6,640.48$ & $\$ 35.824 .48$ \\
\hline & 2" sched. 40 SST piping & 65 LF & 40 & $\$ 1,600.00$ & $\$ 1,612.00$ & $\$ 706.64$ & $\$ 3.918 .64$ \\
\hline & 3" sche 40 SST piping & $45 \mathrm{LF}$ & 32 & $\$ 1,280.00$ & $\$ 2,328,00$ & $\$ 793.76$ & $\$ 4,401.76$ \\
\hline & Tees/ELLS/elbows & 30 ea & 0 & $\$ 0.00$ & $\$ 6,000.00$ & $\$ 1,320.00$ & $\$ 7,320,00$ \\
\hline & Hydro \& flush manifolds & 2 ea & 32 & $\$ 1,280.00$ & $\$ 0.00$ & $\$ 281.60$ & $\$ 1,561.60$ \\
\hline & Pipe supports & $2 \mathrm{ea}$ & 160 & $\$ 6,400.00$ & $\$ 1,078.00$ & $\$ 1,645.16$ & $\$ 9.123 .16$ \\
\hline & Fabricate funnels & 57 ea & 114 & $\$ 4.560 .00$ & $\$ 922.00$ & $\$ 1,206.04$ & $\$ 6,688.04$ \\
\hline & Fabricale reach rods & 57 ea & 228 & $\$ 9,120,00$ & $\$ 922.00$ & $\$ 2,209.24$ & $\$ 12,251.24$ \\
\hline & Install piping manifolds & 2 ea & 80 & $\$ 3,200.00$ & $\$ 0.00$ & $\$ 704.00$ & $\$ 3,904.00$ \\
\hline & Install flexible jumpers & 57 ea & 120 & $\$ 7,200.00$ & $\$ 0.00$ & $\$ 0.00$ & $\$ 7,200.00$ \\
\hline & Install reach rods & 57 ea & 114 & $\$ 6,840.00$ & $\$ 0.00$ & $\$ 0.00$ & $\$ 6,840.00$ \\
\hline & $2 "$ welds & 94 ea & 188 & $\$ 7.520 .00$ & $\$ 0.00$ & $\$ 1,654.40$ & $\$ 9.174 .40$ \\
\hline & 3" welds & 86 ea & 173 & $\$ 6,920.00$ & $\$ 0.00$ & $\$ 1,522.40$ & $\$ 8.442 .40$ \\
\hline & Total WBS 1.3.4 & & 1281 & $\$ 55,920.00$ & $\$ 93.065 .00$ & $\$ 29.687 .90$ & $\$ 178,672.90$ \\
\hline & TOTAL & & 2896 & $\$ 158,920.00$ & $\$ 624,825.00$ & $\$ 29,687.90$ & $\$ 813.432 .90$ \\
\hline
\end{tabular}




\begin{tabular}{|c|l|}
\hline WBS & \multicolumn{1}{|c|}{ Contingency Analysis } \\
\hline 1.1 & $\begin{array}{l}\text { Project Management } 15 \% \\
\text { The overall percentage assigned to this WBS is relatively low since the activities are consistent with past practices. and since the overall } \\
\text { dollar amount is relatively high. Also, the design work scope is relatively simple and straiglut forward and unlikely to be significantly } \\
\text { modified or delayed. }\end{array}$ \\
\hline 1.2 & $\begin{array}{l}\text { Design } 26 \% \\
\text { The overall percentage assigned to this WBS is moderate since recent modifications to other pits have occurred, since design is very } \\
\text { straight forward, and since the allowances for all activities in both direct dollars and escalation rates have been on the high side of } \\
\text { expected ranges. The same methodology has been applied to design during construction and inspection. }\end{array}$ \\
\hline 1.3 & $\begin{array}{l}\text { Construction } 28 \% \\
\text { The overall percentage assigned to this WBS is relatively high due to the fact that it is uncertain how clean the pits will be and how } \\
\text { extensive the cover block modifications will be. The other elements of construction are relatively simple and straight forward. }\end{array}$ \\
\hline 1.4 & $\begin{array}{l}\text { NEPA/Safety Analysis/Permits } 15 \% \\
\text { A relatively low percentage has been applied to this WBS since minimal effort is required. }\end{array}$ \\
\hline 1.5 & $\begin{array}{l}\text { Startup and Testing } \underline{25} \% \\
\text { A moderate percentage has been applied to this WBS since the start up and testing ilctivities int minimal. and straight forward. }\end{array}$ \\
\hline The overall contingency percentage of $27 \%$ is considered very reasonable for this level/type of cstimale.
\end{tabular}




\section{APPENDIX B \\ Project Schedule}

This appendix contains a project schedule at the level of detail necessary to provide sufficient planning information for design and construction activities. 


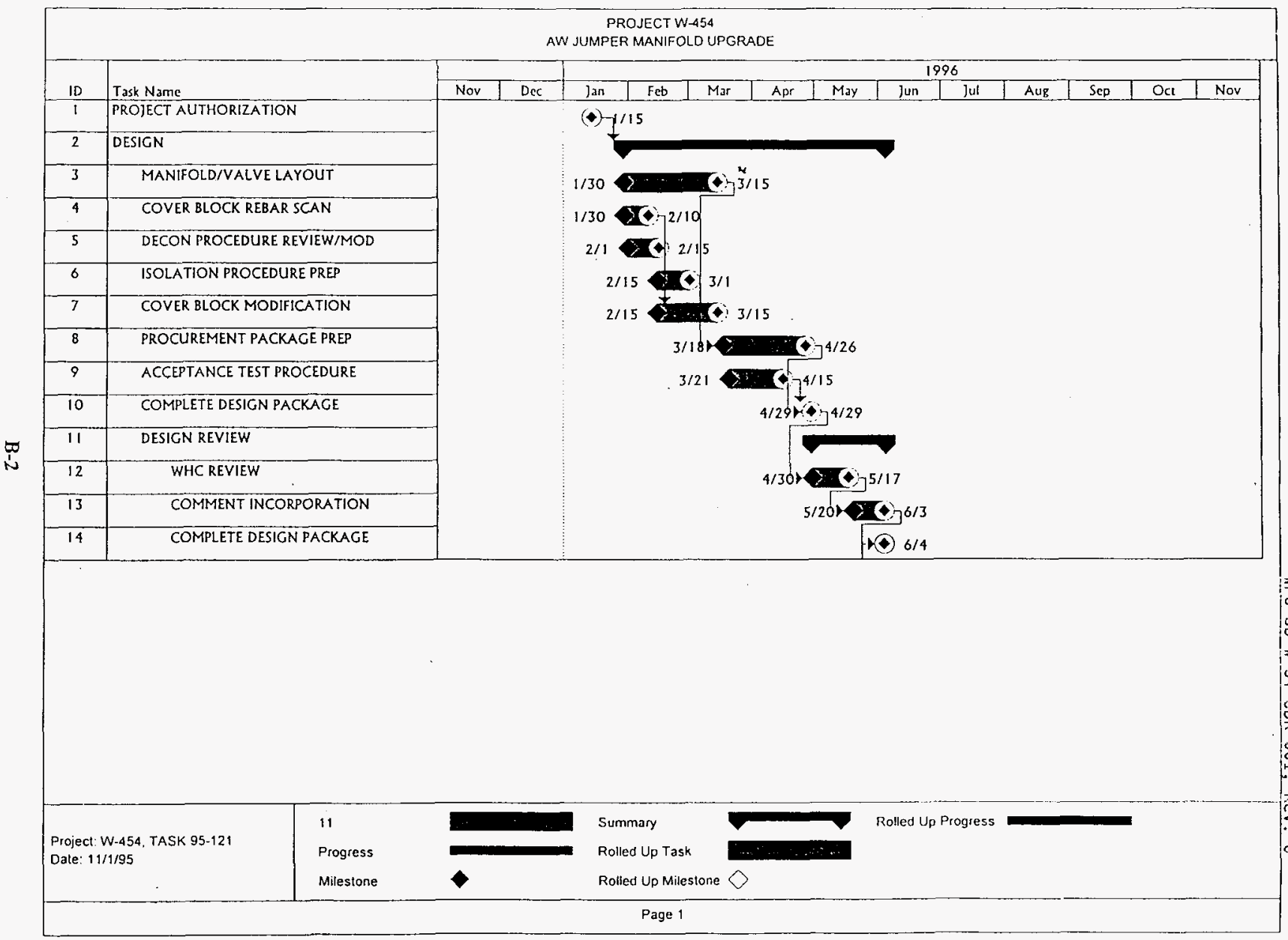




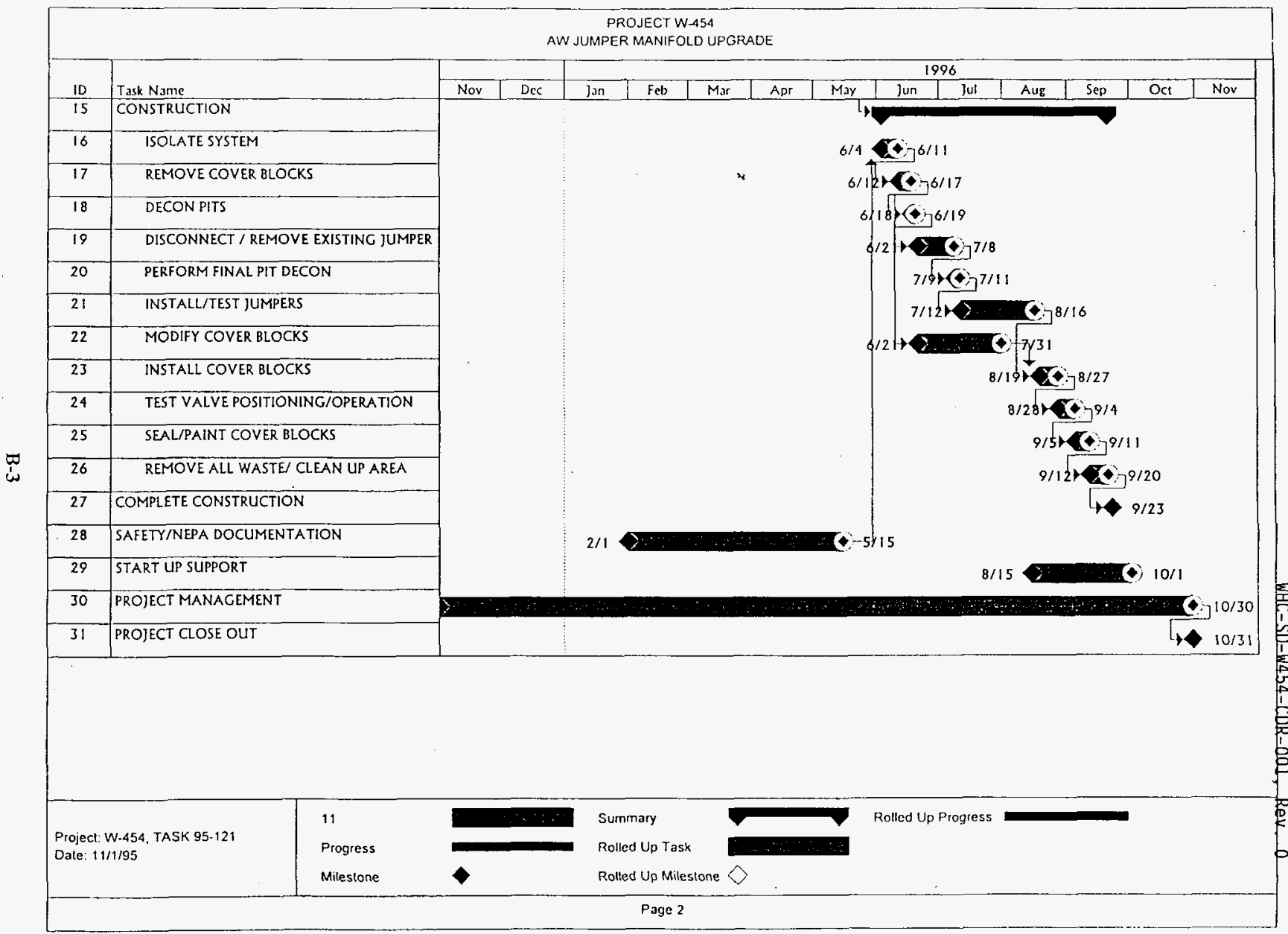




\section{APPENDIX C Current Operating Practices}

This appendix contains information on how the annual operating cost associated with the current configuration of the AW Valve Pits is figured. This cost information serves as the basis for the Life-Cycle Cost Analysis (Appendix D) and the project justification.

The present practice is to store spare jumpers in the valve pits to expedite configuration changes and to keep costs down. Approximately ten jumper configurations are presently stored in each valve pit. The spare jumper configurations increase the difficulty of maintaining pit cleanliness and perform maintenance on leak detection equipment. Additionally, it is difficult to perform integrity assessments on the valve pit concrete walls and to identify evidence of deterioration, cracking, or other conditions that could lead to a containment leak.

When a waste transfer piping routing change is required, the lines are isolated, cover blocks are removed, jumpers are disconnected, and a new jumper to obtain the desired routing is installed.

Entry into the pits (a high radiation area) requires up front support activities prior to performing the actual work, follow up actions to verify work meets applicable requirements, and verification that jumper connections are not leaking. This involves up to ten persons to perform planning, scheduling, safety and quality reviews, job package reviews, and management approvals.

The actual jumper reconfiguration is labor intensive and involves considerable exposure up to a total exposure of .28 person rem per pit configuration modification. A total of 2.8 person rem per year for ten configuration changes could be expended.

A net dose dollar benefit of between $\$ 5,600$ and $\$ 28,000$ per rem is calculated using the WHC Occupational ALARA Program optimization methodology. Although project cost is not justified solely by ALARA, real benefits are provided and there is reduced potential for worker contamination.

The total cost for a jumper reconfiguration exceeds $\$ 30,000$. It is anticipated that a minimum of ten reconfigurations per year will occur. The actual number could be considerably higher based on evaporator usage. 


\section{APPENDIX D \\ Life-Cycle Cost Analysis}

This appendix contains a Life-Cycle Cost Analysis for the estimated operating costs associated with current practices and the initial and long-term costs of Project W-454. 


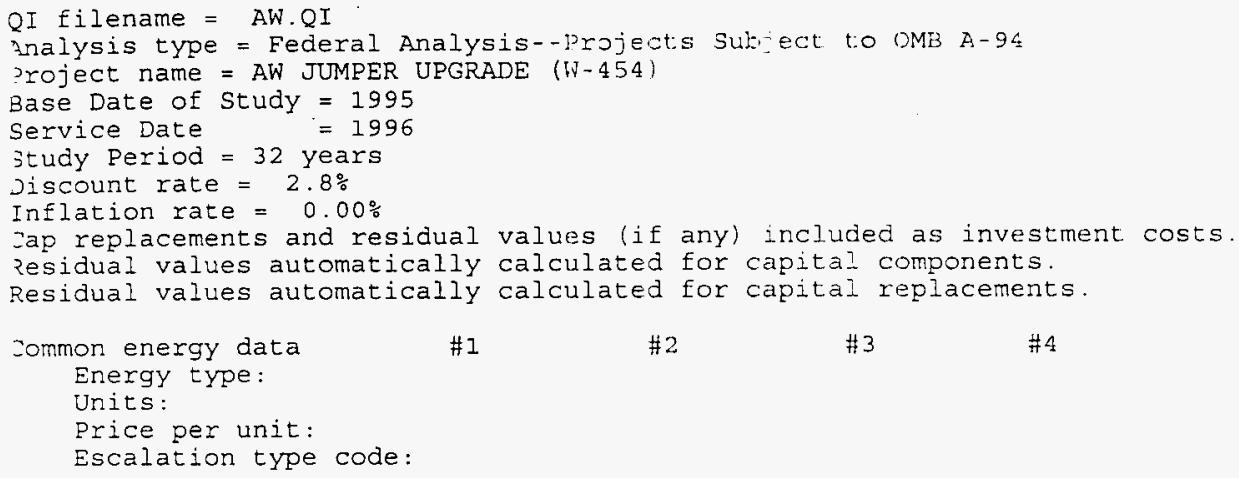


BLCC Quick Input Program (QI2.1-95) 11-01-1995/13:13:41

QI filename $=A W . Q I$

Analysis type = Federal Analysis--Projects subject to omB A-94

Project name = AW JUMPER UPGRADE $(W-454)$

Base date of study $=1995$

Service date $=1996$

Study Period $=32$ years

Service Period $=31$ years

Discount rate $=2.8 \%$

Annually recurring costs and energy costs discounted from end of year.

Number of alternatives in file $=2$

Number of groups in file $=1$

Note: Project alternatives displayed in increasing order of investment cost

\begin{tabular}{|c|c|c|c|c|}
\hline Group code: & $--_{-}-{ }_{-}$ & -Present- & alue Costs. & $\ldots \ldots \ldots$ \\
\hline Alternative & Investment & $O M \& R$ & Energy & Total Life- \\
\hline Name & $\operatorname{costs}{ }^{*}$ & Costs & Costs & Cycle costs \\
\hline$--\cdots----$ & ---------- & -------- & $\ldots$ & $-\ldots \ldots$ \\
\hline $\begin{array}{l}\text { BASELINE } \\
\text { MANI FOLD }\end{array}$ & $\begin{array}{r}\$ 0 \\
\$ 1798931\end{array}$ & $\begin{array}{r}\$ 5994701 \\
\$ 199823\end{array}$ & $\begin{array}{l}\$ 0 \\
\$ 0\end{array}$ & $\begin{array}{l}\$ 5994701 \\
\$ 1998754<--M I N \quad L C C\end{array}$ \\
\hline
\end{tabular}

Comparative measures are only calculated for the alternative with lowest LCC relative to alternative with the lowest present-value investment cost.

Comparative economic measures for MANIFOLD relative to BASELINE:

NET SAVINGS $=\$ 3995948 ;$ SIR $=3.22 ; A I R R=6.63 \%$

Ratio of present-value energy savings to total savings $=0.00$

* Investment costs include capital replacements and residual values (if any). Residual values for initial capital investment are calculated when life extends beyond end of study period.

Residual values for capital replacements are calculated when life extends beyond end of study period. 


\section{APPENDIX E Design Drawings}

This appendix contains a Procurement Data Sheet for the manifold components, flow connection drawings to verify routings, and a plan view layout to confirm adequate space is available for all components. 


\section{PROCUREMENT DATA SHEET \\ AW JUMPER MANIFOLD UPGRADE}

\section{Valve Manifolds:}

1. Arrangement shown on drawings (Appendix D).

2. Piping designed fabricated and inspected in accordance with ASME 831.3-1992 Edition.

3. Stainless Steel Pipe: ASTM A312 -91b Seamless and Welded Austenitic Stainless Steel Pipes.

4. Stainless Steel Pipe Fittings: A 403-91 Wrought Austenitic Stainless Steel Piping Fittings.

5. Two-Port Stainless Steel Valves with Ultra High Molecular Weight Polyethylene seat, seal and stem packing material: Pittsburgh Brass Manufacturing Company Model 2" SP-HL-37. BW-UHMWPE and 3" SP-HL-39-BW-UHMWPE.

6. Three-Port Stainless Steel Valves with Ultra High Molecular Weight Polyethylene seat, seal and stem packing material: Pittsburgh Brass Manufacturing Company Model 2" MP-H-37. BW-2-PO-CO-BO-E8-H5-S6-AO-1P and MP-H-39-BW-2-PO-CO-BO-EB-H5-S6-AO-1P.

7. PUREX Connectors: as shown on Drawings H-2-90185 and H-2-90186.

8. Support Channels: ASTM A36

\section{Other:}

9. Flexible Jumper Assemblies: as shown on Drawing $\mathrm{H}-2-96873$ (3" jumpers) and $\mathrm{H}-2-\mathrm{XXXXX}$ (2" jumpers).

10. Funnels: as shown on Drawing H-2-90171.

11. Reach Rods: as shown on Drawing H-2-90172.

12. Lifting Bails: as shown on Drawing H-2-901.61 
VAlve PIt 241-AW-A CONNection DIagrail - SluRry and SlPERNatant PIPING

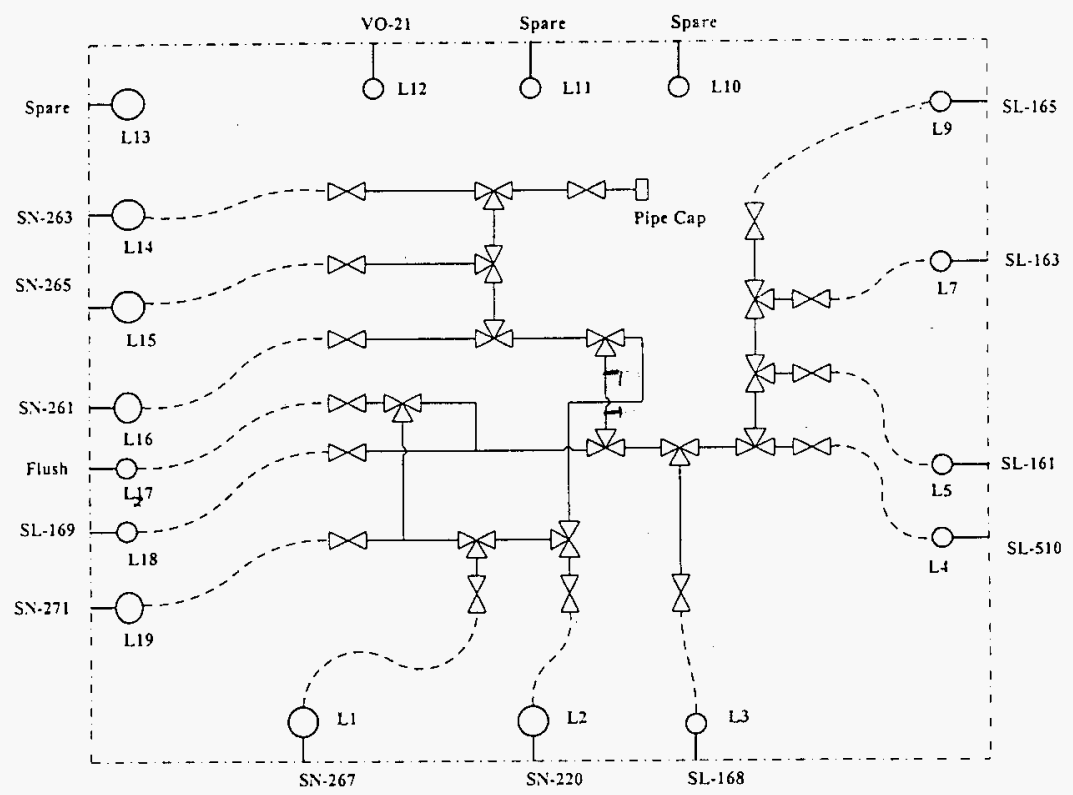

LEGEND

\begin{tabular}{lll}
\hline 2-way valve & $\cdots \cdots$ & Flexible Jumper \\
3-way valve & $\cdots \cdots$ & Pit Wall \\
$0 \quad$ Pil Nozzle & & \\
\hline
\end{tabular}

CDLR-W454-SK-1

E-3 


\section{VALIE PIT 241-AW-B CONECTION DIAGRAM -- SUPERNATANT PIPIYC}

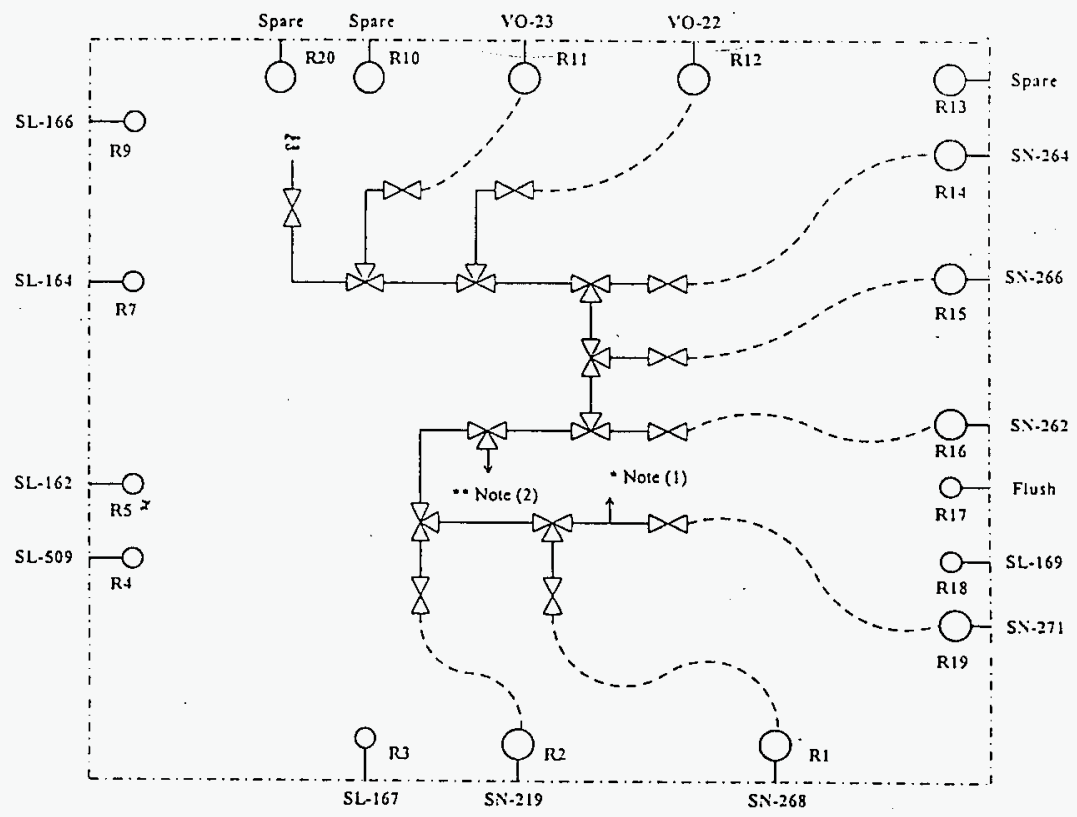

LEGEND

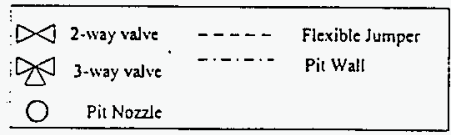

Note (1) This piping (flush water) continues at the ${ }^{*}$ on the Valve Pit 241.AW-B Flow Connection Diagram - Slumy Piping.

Nole (2) This piping (slumy-supernatant cross-connect) continues at the * on the Valve Pit 24l-AW.B Flow Connection Diagram - Slumy Piping.

\section{CDLR-W454-SK-2}




\section{$\varepsilon-Y S-\mapsto s \triangleright \Lambda 1-\mathrm{dTa \supset}$}
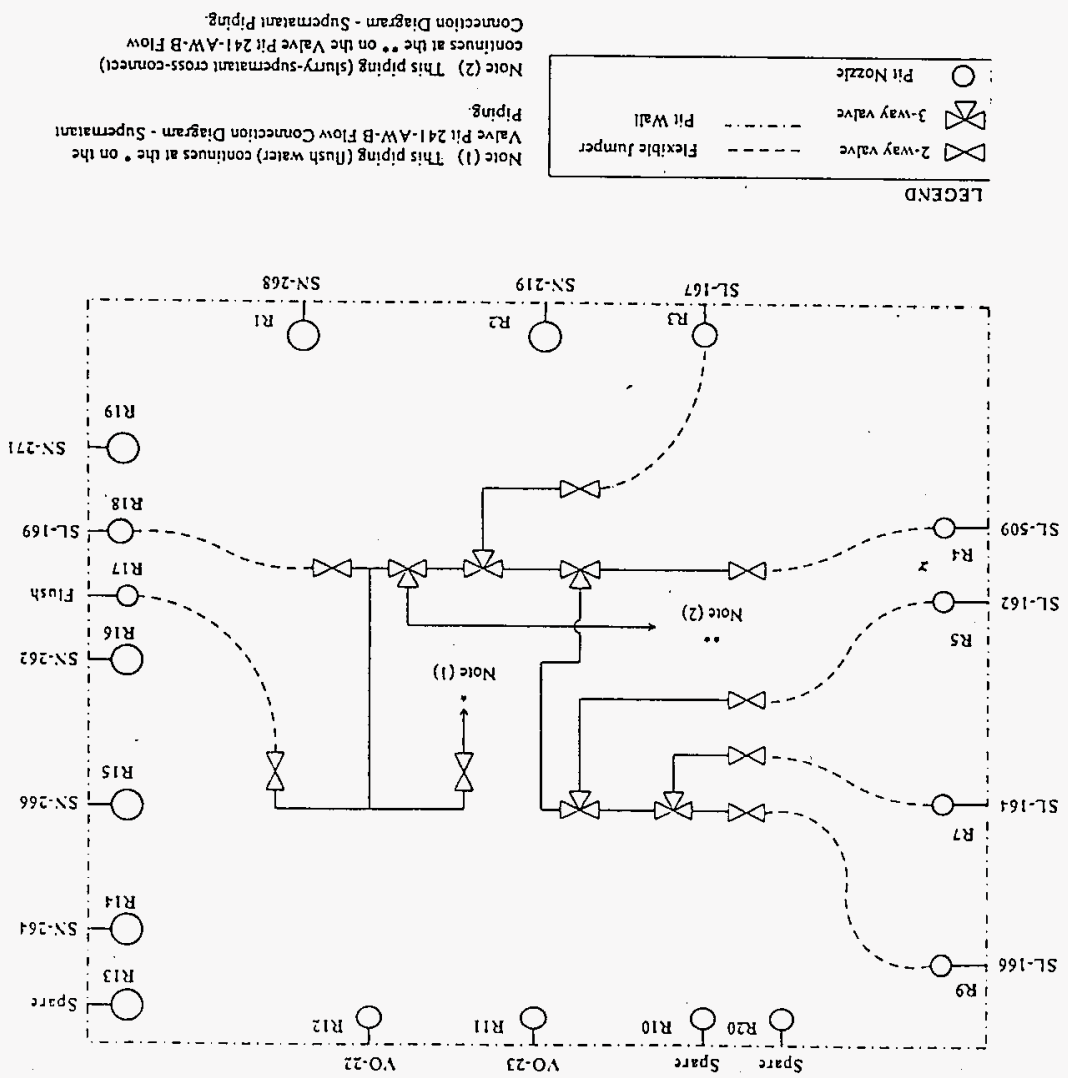

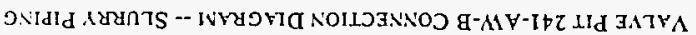




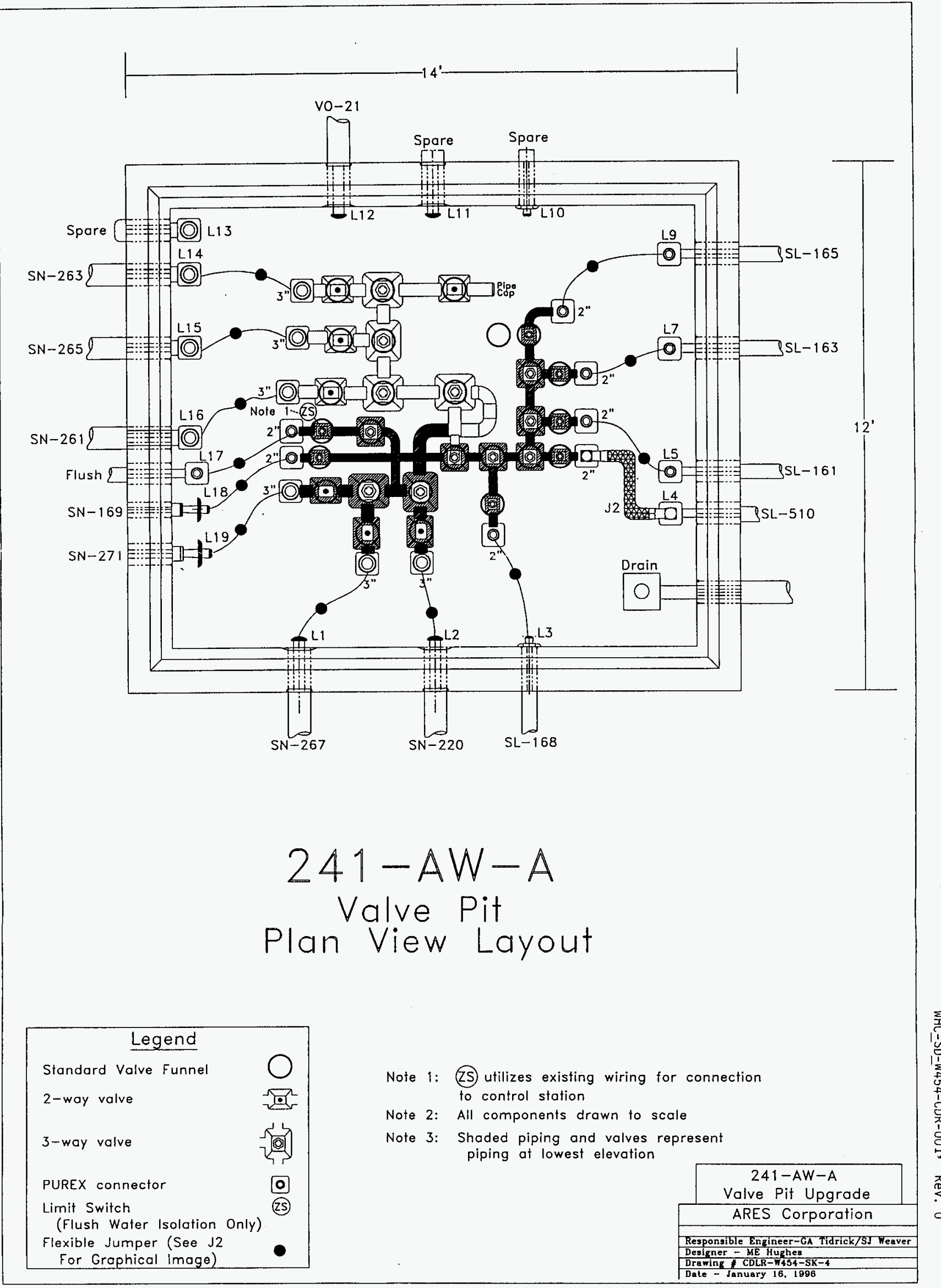




\section{InOKD 7 Mə!^ UDId \\ $t ! d \quad \partial \wedge \mid D \wedge$

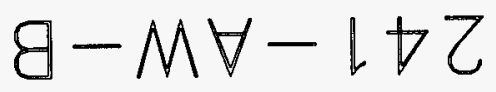

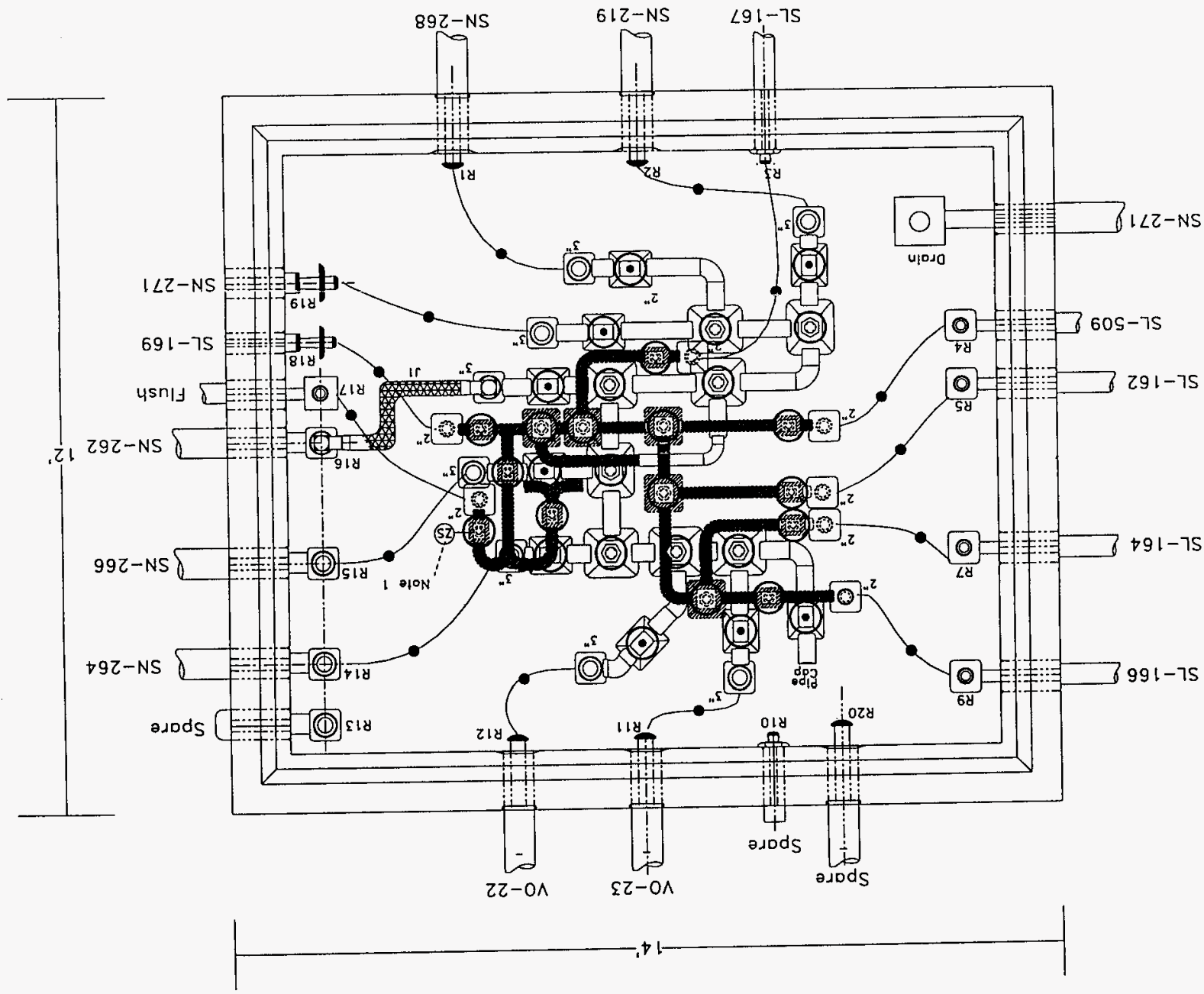

